\title{
Trabalhonecessário
}

Issn: 1808 - 799X

ano 13 , número $20-2015$

\section{A ESCOLA DE GRAMSCI: VINTE E DOIS ANOS DEPOIS ${ }^{1}$}

Paolo Nosella ${ }^{2}$

\section{Resumo}

O texto é uma releitura crítica do livro A escola de Gramsci, publicado em 1992. Rememora motivações da obra e circunstâncias da época e indaga se os recentes estudos sobre o patrimônio literário de Antônio Gramsci aconselham ajustes ou ênfases novas. Conclui que, permanecendo válidos os aspectos essenciais do livro, sobretudo, a estrutura geral, o recorte teórico e as informações sobre a história da Itália, hoje é preciso enfatizar a constante preocupação teórico-prática de Gramsci: operar um profundo revisionismo da vulgata marxista e dos fundamentos do bolchevismo.

Palavras-chave: Gramsci; Política; Escola.

\section{Abstract}

The text is a critical relecture of the book "A escola de Gramsci", published in Brasil in 1992. Reminds the motivation and the circuntances of the book's writing and questions if the recent studies on the literary patrimony of Antonio Gramsci advise on adjustments or new emphasis. The text concludes that, remaining valid the essential aspects of the book, above all, it's general structure, it's theoretical

\footnotetext{
1 Palestra proferida no II INTERCRÍTICA, do Grupo de estudos e pesquisas sobre trabalho e educação (GEPTE), na Universidade Federal do Pará (UFPA), em 28 de agosto de 2014, BelémPA. O titulo da palestra refere-se ao livro de minha autoria A escola de Gramsci, 4 ed. - Editora Cortez, São Paulo-SP, 2010, cuja primeira edição ocorreu pela Editora Artes Médicas Sul, Porto Alegre, em 1992, há vinte e dois anos.

2 Professor do Programa de Pós-Graduação em Educação da Universidade Nove de Julho (UNINOVE). Professor colaborador do Programa de Pós-Graduação em Educação da Universidade Federal de São Carlos (UFSCAR).
} 


\section{Trabalhonecessário}

Issn: 1808 - 799X

ano 13, número $20-2015$

cutting and the information on the Italian history, nowadays it is necessary to enphazyze Gramisci's constant theoretic-practical worrying: to operate a deep revisionism of the marxist vulgata and the fondaments of bolchevism.

Key words: Gramsci. Politics. School.

Entre fazer um filho e publicar um livro, há uma diferença especial: o filho situa-se sempre no futuro, o livro permanece sempre no passado. Por isso, ao filho é necessário rememorar ciência, tradições e valores do passado; do livro é oportuno relembrar as circunstâncias da publicação, as leituras que dele foram feitas, os novos estudos e debates sobre a temática. É impossível atualizar um livro. Sua redação original exibirá sempre as marcas do tempo. Quanto muito, novas páginas, à guisa de prefácio ou posfácio datados, servirão de "atualização". É justamente isso que tentarei fazer agora, neste texto, vinte e dois anos depois da $1^{\text {a }}$ edição do livro $A$ escola de Gramsci. Agradeço os organizadores deste evento pela oportunidade e homenagem.

Sua primeira edição é do ano de 1992. Visava a fornecer aos educadores brasileiros informações essenciais da história da Itália das primeiras décadas do século XX, época de Gramsci, permitindo-Ihes, com alguns comentários, uma leitura contextualizada dos seus textos, conforme escrevi no "Ao leitor" daquela edição:

Este livro é um acerto de contas com certa leitura abstrata e fragmentária que os educadores brasileiros, na grande maioria, fazem de Gramsci. A forma escolástica de se ler um autor lhe confere uma sobrevivência abstrata e mítica que, mais cedo ou mais tarde, desmorona como tudo o que é falso e artificial. Ora, como se ler Gramsci em seu contexto histórico, sem conhecer a história italiana das primeiras décadas do século? (Nosella, 2010. p. $23,4^{\mathrm{a}}$ ed.) 


\section{Trabalhonecessário}

Issn: 1808 - 799X

ano 13, número $20-2015$

Essas linhas redigidas em 1991 sintetizam a razão que me levou a escrever o livro. Todavia, seu tom, hoje, me faz um pouco sorrir: de formação italiana, preocupado com os leitores brasileiros que pouco conheciam a história da Itália e, sobretudo, por temperamento, amante dos debates, calquei a mão quando escrevi que a leitura dos textos gramscianos na década de 1980 era descontextualizada e, também, "artificial e falsa". Hoje, reformularia essa afirmação. Era, e continua sendo, uma leitura politicamente engajada, sincera, genuína, mesmo que a questão do a-historicismo permaneça ainda aberta, como veremos a seguir.

A divulgação do livro não foi grande, mas ia pingando sem parar. A segunda edição ocorreu em 1998. Em 2004, a Editora "Artes Médicas" de Porto Alegre me informou que encerraria a "Série educação, teoria \& crítica" e, portanto, liberava o livro para que eu pudesse republicá-lo por outra editora. A "Cortez Editora" de São Paulo aceitou e publicou, no mesmo ano, a terceira edição, revista e atualizada, acrescida pelo Epílogo "Gramsci e os educadores brasileiros: um balanço crítico". Dermeval Saviani a abrilhantou com "Apresentação à $3^{a}$ edição". Hoje, pouco a pouco, esgota-se a 4⿳⺈冂a edição.

Meu guia e mestre, Mario Alighiero Manacorda, havia-me aconselhado a "costurar" os textos de Gramsci, seguindo a cronologia de sua redação, apostilando-os com comentários que destacassem os eventos mais importantes da história política e social do momento. A seleção dos textos obedeceu ao critério da relação entre trabalho e educação, minha preocupação teórica principal. Terminada a pesquisa, enviei a Mário um exemplar do livro, solicitando-lhe um retorno crítico que, gentilmente, me enviou em junho de 1993:

Caro Paolo (...). Em seu livro apreciei muito o escrúpulo filológico, que, obviamente, não consiste apenas na atenção ao desenvolvimento cronológico das ideias, mas também na consciência de que, atrás de cada escolha prática do autor, abrese sempre, como você mesmo diz, um horizonte de novos valores. Aprecio sua consideração da diferença entre as palavras escritas 


\section{Trabalhonecessário}

Issn: 1808 - 799X

ano 13 , número $20-2015$

e as lidas que deixa aberto o caminho para outras interpretações. (in: Manacorda, carta a Paolo Nosella. Arquivo pessoal) ${ }^{3}$

Gostei dos elogios. Sobretudo, de ele ter destacado a diferença entre as palavras escritas e as palavras lidas: "entre quem fala (ou escreve) e quem escuta (ou lê) interpõe-se um espaço misterioso: a frase e a informação redigidas nem sempre ressoam uníssonas no autor e no leitor." (Nosella, 2010, págs. 25-26). Manacorda, historicista, destacara esse "espaço misterioso" no qual amoitam, mas interferem, a "fortuna" (= acaso) e o "livre arbítrio" (= subjetividade); de onde podem surgir os medos, mas também as esperanças; a barbárie, mas também a liberdade; o conservadorismo, mas também o espírito revolucionário.

Contudo, o espaço misterioso entre o sentido êmico do texto do momento da redação e o sentido ético do momento da leitura não dispensa o leitor de buscar sua exata compreensão semântica, sem a qual a leitura será superficial e oportunista. Foi justamente no intuito de possibilitar essa melhor compreensão que escrevi o livro, guiando o educador brasileiro numa imersão cultural da trajetória de Gramsci nas primeiras décadas do século XX. Manacorda entendeu essa preocupação, a tal ponto que a considerou a chave do livro:

Talvez, justamente nesta sua intenção de 'traduzir' Gramsci para o Brasil e para a atualidade consista a chave para compreender seu procedimento. Afinal, quando se parte de uma precisa compreensão do texto, e não o se queira trair, esta é sempre a melhor forma de lê-lo. (Manacorda, idibem. Arquivo pessoal).

Todavia, esse destaque à 'chave' de leitura do livro, ao mesmo tempo em que soou como elogio, deixava transparecer perplexidade: Confesso que à primeira vista fiquei um tanto surpreendido pelo pequeno espaço atribuído aos Cadernos (do cárcere) comparando com os escritos anteriores (Manacorda, ibidem).

${ }^{3}$ Os textos originalmente em língua italiana foram traduzidos por mim, salvo "Studi difficili" e "Cronoche dell'Ordine Nuovo [XI]" in: L'Ordine Nuovo (1919-1920) que foram traduzidos por Vagno Emygdio Machado Dias. 


\section{Trabalhonecessário}

Issn: 1808 - 799X

ano 13 , número $20-2015$

Na verdade, não pretendia oferecer ao leitor brasileiro o pensamento de um prisioneiro, mas o pensamento de uma vida: a de um intelectual italiano, vindo em 1911 da Sardenha para Turim, berço da indústria e dos mais vivos movimentos políticos da época, militante e dirigente comunista condenado a passar os últimos onze anos de vida no cárcere fascista, trágico reflexo do conflito entre fascismo e comunismo. Na cadeia, preocupado pela direção que tomara o movimento comunista internacional, em inúmeras cartas e trinta e três cadernos, lavrou um pensamento amadurecido, mas coerente, na essência, com seu posicionamento político expresso nos escritos anteriores. Manacorda compreendeu essa minha intenção e acabou justificando o "pequeno espaço atribuído aos cadernos":

Parece-me que, além da forte concentração de pensamento das últimas páginas, foi justamente a ampla elaboração dos temas desenvolvidos antes do cárcere que permitiu essa síntese por sinal de exemplar clareza. [...] Para mim é muito bonito constatar que o jovem discípulo caminha muito bem com seus pés nas pegadas do velho mais ou menos 'mestre' e sabe pensar de seu modo. (Manacorda, ibidem, arquivo pessoal)

Bondade dele.

Em 2004, como disse, para a $3^{\text {a }}$ edição, pedi ao meu orientador de mestrado e doutorado, Dermeval Saviani, o favor de redigir a apresentação. De pronto, com a disposição e bondade que o caracterizam, aceitou glosando: "Mas... que favor? Muito ao contrário, é Paolo que me honra ao me fazer esse pedido" (Saviani, 2004, p. 11).

Havia-Ihe perguntado, um pouco retoricamente, se faria sentido insistir na divulgação de um marxista no mercado da pós-modernidade. Ele transformou esta pergunta em trampolim para um oportuno acerto de contas no difuso e confuso emaranhado de teorias provocadas pelo esgotamento da experiência do socialismo real. Primeiramente, respondeu ao alardeado desparecimento ou "morte do marxismo", precisando o conceito de ortodoxia marxista ou método da análise concreta. Respondeu também às críticas de a-historicismo que, em geral, são dirigidas às leituras que educadores brasileiros (nem todos) fazem dos textos 


\section{Trabalhonecessário}

Issn: 1808 - 799X

ano 13, número $20-2015$

de Gramsci. Concluiu, reiterando a necessidade de se analisar a situação política e econômica atual do Brasil à luz das categorias teóricas de Gramsci. Entre essas, destacou o conceito de sociedade civil e de transformismo. Assim, respondendo à minha pergunta, escreveu:

Em boa hora vem a público esta terceira edição de 'A escola de Gramsci'. Sua divulgação é mais do que oportuna em vista dos percalços políticos, sociais, econômicos, culturais e educativos pelos quais estamos passando no momento presente. (Saviani, 2004, p.20).

A apresentação de Saviani conduz o leitor para o amplo espaço das análises teóricas, justificando a priorização da categoria trabalho, recorte teórico principal do livro. Suas argumentações oferecem importantes argumentações, até mesmo de lógica formal (silogismos), para contrapor-se à crise teórica contemporânea, chamada crise dos paradigmas, mesmo que certos problemas, obviamente, permaneçam abertos, como, por exemplo, o da hegemonia e o do historicismo.

Manacorda e Saviani foram leitores especiais. Recebi, todavia, retornos de vários outros leitores. Em geral, todos destacam como pontos positivos do livro o paralelismo entre os textos de Gramsci e a história da Itália, a ênfase dada à concepção de trabalho industrial como princípio educativo e a forma linguística direta e simples que utilizo.

Caberia, agora, perguntar a mim mesmo, vinte e dois anos depois da publicação do livro, o que acho dele. Em mais de duas décadas, muitas coisas acontecem que nos enriquecem e influenciam: o que eu mudaria e o que preservaria, caso viesse a escrever hoje "A escola de Gramsci"?

Continuo gostando do título, da concepção e da estrutura do livro. Considero importante, ainda hoje, destacar o grande interesse de Gramsci pela instituição escolar. Reafirmo também que os dois momentos (antes e durante a prisão) formam uma continuidade espiritual e teórica e se explicam reciprocamente. Considero, enfim, adequada minha opção pela categoria trabalho 


\section{Trabalhonecessário}

Issn: 1808 - 799X

ano 13, número $20-2015$

como critério de recorte dos textos selecionados e comentados, até porque o trabalho, como princípio educativo e pedagógico, continuou sendo a categoria prioritária em meus estudos.

Mas, então, resta perguntar: vinte e dois anos depois da publicação, o que mudaria? As circunstâncias, os debates, os recentes estudos sobre Gramsci aconselham alguns ajustes históricos e teóricos?

Certamente.

Muito me influenciaram as pesquisas de Giuseppe Vacca, Aldo Natoli, Giancarlo Schirru e, em geral, vários estudos publicados pelo Instituto Gramsci de Roma, sobretudo os realizados após a abertura dos arquivos do ex-Partido Comunista Italiano, da ex-União Soviética e das famílias, italiana e russa, de Gramsci.

Também as lutas político-educativas dos educadores no Brasil, nas quais me envolvi nessas últimas duas décadas, sobretudo os debates ocorridos no GT. 09 da ANPEd sobre a Educação Profissional e Ensino Médio, tiveram em mim grande influência. Todo esse conjunto de leituras e discussões, somado à pesquisa que estou desenvolvendo sobre Ensino Médio e às numerosas orientações e participações em bancas relacionadas à temática, me equipa hoje com novos óculos na releitura do livro, de forma que, se fosse reescrevê-lo, algumas páginas receberiam ênfases e ajustes novos que esquematizo em quatro tópicos:

a) a questão ideológico-partidária; b) a questão linguística; c) a questão do historicismo e da dialética; d) a questão da escola unitária do trabalho.

\section{a) A questão ideológico-partidária}

No epílogo da edição de 2004, se lê: 


\section{Trabalhonecessário}

Issn: 1808 - 799X

ano 13 , número $20-2015$

A compreensão da ruptura de Gramsci com o Partido pode nos ajudar a entender melhor a profunda reviravolta histórica que encerrou, em 1989, o século XX, tristemente caracterizado pelas tragédias dos fascismos e dos comunismos [...]. Dentro deste novo quadro de valores e perspectivas, para Gramsci deixou de ser importante voltar a ser um dirigente político. (Nosella, idem ibidem, págs. 201 e 202)

Hoje, é minha obrigação esclarecer melhor o sentido das expressões "ruptura de Gramsci com o Partido" e "para Gramsci deixou de ser importante voltar a ser um dirigente político". Quando redigia essas linhas que, em parte, ainda permanecem verdadeiras, estava influenciado, entre outros, pelo texto de Giuseppe Vacca de 1992: “Antonio Gramsci 1926-1937: a linha de sombra nas relações com o Comintern e o Partido". Esse texto destacava o desentendimento entre Gramsci e Togliatti. Na última sua obra (Vacca, 2012), entretanto, percebese um indisfarçável resgate de Togliatti e do P.C.I., com base em recentes documentos (sobretudo cartas) que o estudioso teve oportunidade de recuperar e analisar, em sentido oposto às persistentes suspeitas de Gramsci de que os dois sabotassem sua liberação. O sentido do verbo "sabotar" permanece historicamente sub judice. Lembro que, em conversa com Vacca, na UNICAMP ${ }^{4}$, num evento em que ele proferia palestra e eu atuava como tradutor, perguntei-Ihe à queima roupa: "Gramsci rompeu com Togliatti?". De pronto, respondeu-me: "O que seria de Gramsci sem Togliatti?". Essa resposta está implícita nas últimas linhas do seu recente livro:

Por uma frequente heterogênese dos fins, a carta das irmãs Schucht teve um resultado contrário ao que elas desejavam [afastar Togliatti dos manuscritos e da herança literária de Gramsci]. Como parece evidente pela composição da Comissão [criada pelo Executivo da Internacional Comunista para elaborar propostas concretas sobre a utilização do patrimônio literário de Gramsci], o destino dos Quaderni foi parar nas mãos de Togliatti e, mais ainda, com o aval de Stalin. (Vacca, ibidem, p. 359)

4 Seminário Internacional - Gramsci e a Educação - UNICAMP, Campinas, 19 a 23 de outubro de 2009. 


\section{Trabalhonecessário}

Issn: 1808 - 799X

ano 13 , número $20-2015$

Nenhum historiador duvida, todavia, que as relações de Gramsci com Togliatti, o Partido Comunista da Itália (Pcd'l) e o Comintern estavam estremecidas. Mas, de minha parte, teria sido mais exato escrever que, entre Gramsci, o P.C.d'l e o Comintern, não houve ruptura formal, porém, ideológica, política e até afetivamente o desentendimento foi profundo e progressivo, sobretudo, desde 1926.

Como confirmação desse desentendimento teórico e político, há páginas definitivas na citada obra de Vacca, sobretudo no primeiro e no XIII capítulos "A heterodoxia gramsciana" e "O códice Croce". O autor, nas orelhas do livro, faz a seguinte síntese:

$\mathrm{Na}$ sua condição [de prisioneiro], Gramsci percebe reflexos os dramas da 'grande história' e elabora uma profunda revisão do bolchevismo: a concepção da política e do Estado, a análise da situação mundial, a teoria da crise e da doutrina da guerra. Nos Cadernos do cárcere sedimenta-se, portanto, um novo pensamento com o qual entendia batalhar, uma vez fora do cárcere, para mudar a direção do movimento comunista. (Vacca, 2012, orelha do livro)

Vacca defende, com fundamentos, a tese de que o trabalho teórico de todos os Cadernos do Cárcere de Gramsci visava a um profundo revisionismo do bolchevismo, sobretudo do ultrabolchevismo de Stalin. Utilizando a expressão de Leonardo Galastri, visava a uma "recomposição do marxismo" (Galastri, 2013, p.107), prática e teoricamente empobrecido e até deteriorado pela vulgata marxista. Esse grande objetivo teórico estruturante de toda a obra de Gramsci nos faz entender também a razão de por que ele jamais rompeu formalmente com o Partido, uma vez que tinha consciência da importância e responsabilidade de seu trabalho político-teórico na "desventura" incipiente do movimento comunista internacional. Gramsci nunca deixou de se considerar dirigente responsável pelo destino político do proletariado italiano e internacional. $\mathrm{Na}$ época, perdeu a batalha; hoje, a história Ihe dá razão. 


\title{
Trabalhonecessário
}

Issn: 1808 - 799X

ano 13 , número $20-2015$

Se hoje escrevesse A escola de Gramsci, também insistiria na ideia de que as divergências de Gramsci com a vulgata marxista aparecem em seus escritos desde o início de sua carreira de militante socialista e escritor, bem antes, portanto, da conhecida crise com o Comintern e o PCd'l de 1926. Com efeito, o debate sobre a chamada "crise do marxismo" na Itália e na Europa do fim de século XIX e do começo do século XX acentuou-se quando Antonio Labriola publicou, na Itália e na França, três importantes ensaios sobre o marxismo: In memoria del manifesto dei comunisti (1895); Del materialismo storico dilucidazione preliminare (1896); Discorrendo di socialismo e di filosofia (1897), saudados com entusiasmo por muitos intelectuais europeus, sobretudo por Croce na Itália e Sorel na França. Infelizmente, esse entusiasmo desviou, mais tarde, para uma interpretação do marxismo absolutamente heterodoxa, isto é, contrária ao que o próprio Labriola entendia por "filosofia da práxis":

\begin{abstract}
Mas quando, em 1898, pouco depois da publicação do terceiro ensaio Discorrendo di socialismo e di filosofia, esses dois [Croce e Sorel], que, mais do que qualquer outro, pareciam haver-se aproximado à sua maneira de pensar e haviam acolhido com entusiasmo sincero seus ensaios tornando-se deles entusiastas propagadores, evidenciaram, jogando-se de alma e corpo na assim chamada crise do marxismo, um encaminhamento teórico exatamente contrário à indicada por ele [Labriola]. (Gerratana, 1974, p.10)
\end{abstract}

Gramsci chegara à Universidade de Turim em 1911. Leu Labriola no clima cultural influenciado por Croce. Mais tarde, porém, encontrou justamente na leitura marxista do Labriola inspiração para a crítica ao próprio Croce. Em suma, entre a tendência materialista vulgar, que via no marxismo a continuação e desenvolvimento do tradicional materialismo, e a tendência contrária, o idealismo, que integrava o marxismo em outras correntes de pensamento (Gerratana,1974, p. 20/21), viu na posição de Labriola o caminho mais fecundo, conforme ele próprio afirmou nos Cadernos: 


\section{Trabalhonecessário}

Issn: 1808 - 799X

ano 13 , número $20-2015$

$\mathrm{Na}$ realidade, Labriola, afirmando que a filosofia da práxis é independente de qualquer outra corrente filosófica, é autossuficiente, é o único que tenha procurado construir cientificamente a filosofia da práxis. (Gramsci, 1975, pp. 1507-8)

Em conclusão, a problemática sobre ortodoxia ou heterodoxia marxista constitui em Gramsci uma forte linha de pensamento no conjunto de todos os seus escritos, antes e durante o cárcere. Nesse sentido, entre os textos citados e comentados no meu livro caberia acrescentar outros igualmente emblemáticos, como: "A revolução contra o capital (1917)", "O nosso Marx (1918)", "Cronache dell'Ordene Nuovo [XI] (1919)", "O instrumento de trabalho (1920)" etc.

\section{b) A questão linguística}

Quem chamou minha atenção sobre a importância de ler Gramsci como estudioso de linguística foi Giancarlo Schirru, pesquisador do Instituto Gramsci e Professor de Glotologia e Linguística na Universidade de Cassino (It.). Essa nova perspectiva de leitura foi como devolver a vista a um cego: de imediato fica extasiado e perdido na imensidão de novidades. Em toda página, em toda nota de Gramsci comecei a ver marcas do estudioso de linguística.

Schirru me ensinou que Gramsci, estudante de linguística da Universidade de Turim, no mês de abril de 1915 apresentou sua última prova. A necessidade financeira (perdera a bolsa de estudo) o forçou a diminuir o ritmo dos estudos, dedicando-se mais ao trabalho de jornalista na imprensa socialista da cidade. Mas não abandonara o curso:

Continuou a estudar e manteve vivo o projeto de se laurear em linguística, sob orientação do Prof. Matteo Bártoli, até o ano de 1918 ou até os primeiros meses do ano seguinte. (...). Obviamente, nesse período, aproximou-se a muitas disciplinas e cultivou diversos interesses científicos; não há dúvida, porém, que a linguística teve para ele um papel central; desde o primeiro ano de universidade demonstrou um interesse privilegiado por esse 


\section{Trabalhonecessário}

Issn: 1808 - 799X

ano 13 , número $20-2015$

setor de estudos no qual dedicará seu maior empenho também nos anos seguintes. (Schirru, 2011, p. 926)

Com essa informação, fica mais fácil entender por que na conhecida carta a Tânia de 19/03/1927, em que comunica sua ideia de escrever algo für ewig, isto é, de caráter "desinteressado" e "de longo alcance", entre os quatro grandes temas interligados que entende desenvolver, o segundo é nada menos que um estudo de linguística comparada: "Um estudo de linguística comparada! Nada menos que isso. Mas o que poderia ser mais 'desinteressado' e für ewig do que esse tema?" (Gramsci, 1975, vol. 1, p. 128).

Creio mesmo que, vinte e dois anos depois, meu livro deva destacar um Gramsci especialista e apaixonado pela linguística. Não por razões de erudição, mas porque a linguagem para ele é expressão viva da concepção de vida, do senso comum popular, da cultura em geral. É o instrumento fundamental da filosofia da práxis, da educação, da escola e, sobretudo, da hegemonia política. Com efeito, palavra, conceito e prática, embora não se identifiquem, são fortemente correlatos: são os anéis de uma corrente, aparentemente desarticulados e autônomos, que, de fato, formam um bloco, uma unidade política cultural. Por outra metáfora: uma língua é um instrumento técnico que, à guisa do cometa com larga e longa cauda luminosa, cria uma linguagem, isto é, uma cultura, uma filosofia coletiva, uma forma de falar e de expressar interesses de um determinado conjunto social:

Posta a filosofia como concepção do mundo - e o trabalho filosófico sendo concebido não mais apenas como elaboração 'individual' de conceitos sistematicamente coerentes, mas, além disso, e sobretudo, como luta cultural para transformar a 'mentalidade' popular e difundir as inovações filosóficas que se revelem 'historicamente verdadeiras' na medida em que se tornem concretamente, isto é, histórica e socialmente, universais -, a questão da linguagem e das línguas deve ser 'tecnicamente' colocada em primeiro plano. (Gramsci, 1999, vol.1, p. 398) 


\section{Trabalhonecessário}

Issn: 1808 - 799X

ano 13 , número $20-2015$

Gramsci, quando analisa criticamente não apenas o ultrabolchevismo stalinista, mas também o marxismo bolchevique russo no seu conjunto, se utiliza da linguística como um instrumento essencial. Assim, por exemplo, demonstra preocupação com a "tradução" de Marx, Engels e do próprio Lenin. A denominação de "filosofia da práxis" em lugar de "materialismo histórico" é uma emblemática e significativa "tradução histórica", não é "criptologia carcerária" como às vezes foi dito. Merece aqui citar um trecho da nota II ${ }^{\underline{a}}$ do Caderno $11, \S$ 27. É uma frase atribuída a Napoleão conversando em Bolonha com alguns cientistas, entre os quais A. Volta. Gramsci faz essa citação com óbvio sentido de concordância:

...eu acredito que, quando nas ciências se encontra alguma coisa realmente nova, é preciso atribuir-lhe um termo totalmente novo, a fim de que a ideia permaneça precisa e distinta. Se atribuírem novo significado a um velho termo, por tanto que professem que a antiga ideia colada àquela palavra nada tem a ver com a ideia novamente atribuída, as mentes humanas não mais podem considerar que haja alguma semelhança e conexão entre a antiga e nova ideia; e isso embrulha a ciência e produz inúteis disputas. (Gramsci, 1975, pp. 1437-38)

Outro emblemático exemplo de recurso aos instrumentos da linguística em sua obra de recomposição ou tradução do materialismo histórico é a análise do texto de Lênin de 1913, "Três fontes e três partes integrantes do marxismo", à luz do conceito de "traducibilidade" das linguagens científicas e filosóficas. Gramsci pergunta-se, várias vezes (ex. Caderno 11, cap. V), sobre a "traducibilidade recíproca de várias linguagens filosóficas e científicas" (idem, ibidem, 1975, p. 1468).

O objetivo central da indagação de Gramsci era compreender o sentido preciso da "integração" na filosofia da práxis entre filosofia clássica alemã, literatura e prática política francesa e economia clássica inglesa. A objeção de Gramsci é que no materialismo marxista da vulgata russa, elaborada por Lênin e que remontava a Plechanov, as três fontes haviam sido apenas justapostas. Ora, 


\section{Trabalhonecessário}

Issn: 1808 - 799X

ano 13 , número $20-2015$

a justaposição dos três grandes movimentos culturais do século XIX no materialismo histórico marxista foi fruto, na crítica de Gramsci, da sociologia de marca positivista. Tal crítica encontrava-se já nos estudos de Labriola (Vacca, 2012, p. 210).

Não é fácil compreender o sentido dessa "integração" que preserve a originalidade da filosofia da práxis. Mas, no caderno n. 10, $\$ 9$, encontra-se uma pista:

O momento sintético unitário, creio, deve ser identificado no novo conceito de imanência, que da sua forma especulativa, tal como era apresentada pela filosofia clássica alemã, foi traduzido em forma historicista graças à ajuda da política francesa e da economia clássica inglesa. (Gramsci, 1999, vol. 1, 317)

E Schirru observa que as notas dos Cadernos

'demoram longamente, e não sem oscilações, sobre as modalidades de como descrever essa conexão [entre filosofia, política e economia], ou seja, de 'como a filosofia da práxis chegou à síntese dessas três correntes vivas na nova concepção de imanência, depurada de qualquer vestígio de transcendência e de teologia'. (Schirru, 2008, p. 421).

Em outras palavras, o recurso de Gramsci à ciência linguística leva-o ao reconhecimento da autonomia de cada linguagem, valendo-se do rigor científico da 'traducibilidade' entre si. Dessa forma, rechaça as tentativas da vulgata marxista de identificar as diferentes linguagens. Mantém com isso a filosofia da práxis nos mais elevados níveis da disputa teórica da primeira metade do século XX. Em outras palavras, pelo recurso à ciência linguística vence a tentação do bolchevismo de reduzir o marxismo a um instrumento político contingencialmente útil, a uma identificação mecânica e interesseira entre política, filosofia e economia, bem como entre poesia, música, arte em geral, respondendo, com isso, também a Croce, que criticava o historicismo marxista como uma mítica 


\section{Trabalhonecessário}

Issn: 1808 - 799X

ano 13 , número $20-2015$

filosofia para a qual a economia seria o determinante metafísico da história enquanto a moral, a filosofia e a arte seriam meras aparências.

Também com referência à concepção de hegemonia, Gramsci recorre à linguística, primeiramente, "traduzindo" a expressão de Lenin "hegemonia do proletariado" para "hegemonia política ou civil". Em seguida, no $§ 44$ do Caderno 10, recorre à linguística operando um verdadeiro "giro epistemológico" de trezentos e cinquenta graus entre o princípio de teoria política e sua difusão linguística, entre relação política de hegemonia e sua relação pedagógica. Tratase de uma "identificação" sui generis entre política, pedagogia e processo hegemônico, no reconhecimento da recíproca autonomia dessas linguagens:

Parece que se possa dizer que 'linguagem' é essencialmente um nome coletivo, que não pressupõe uma coisa única nem no tempo nem no espaço. Linguagem significa também cultura e filosofia (ainda que no nível do senso comum) e, portanto, o fato 'linguagem' é, na realidade, uma multiplicidade de fatos mais ou menos organicamente coerentes e coordenados: no limite, podese dizer que todo ser falante tem uma linguagem pessoal e própria, isto é, um modo pessoal de pensar e sentir. A cultura, em seus vários níveis, unifica uma maior ou menor quantidade de indivíduos em estratos numerosos, mais ou menos em contato expressivo, que se entendem entre si em diversos graus etc. (...). Disto se deduz a importância que tem o 'momento cultural' também na atividade prática (coletiva), isto é, pressupõe a conquista de uma unidade 'cultural-social' pela qual uma multiplicidade de vontades desagregadas, com fins heterogêneos, solda-se conjuntamente na busca de um mesmo fim, (...). Já que assim ocorre, revela-se a importância da questão linguística geral, isto é, da conquista coletiva de um mesmo 'clima' cultural. (Gramsci, 1999, vol. 1, p. 399).

estabelecimento de reciprocidade completa entre processo político e conquista de um mesmo clima cultural leva o autor à obvia conclusão de que toda relação de 'hegemonia' é também uma relação pedagógica (idem ibidem). Não, todavia, de qualquer pedagogia, mas da moderna pedagogia, segundo a qual, "a relação entre professor e aluno é uma relação ativa, de vinculações recíprocas, e, portanto, todo professor é sempre aluno e todo aluno, professor." (idem, ibidem). A 


\section{Trabalhonecessário}

Issn: 1808 - 799X

ano 13 , número $20-2015$

reciprocidade entre processo político hegemônico e relação pedagógica verificase não apenas no âmbito das instituições escolares, mas também no âmbito de uma nação, em todo o campo internacional e mundial, entre complexos de civilizações nacionais e continentais. (idem, ibidem).

Giancarlo Schirru despertou minha curiosidade e fui ler as anotações de Valentino Gerratana sobre o Caderno B (de traduções) de Gramsci:

Da página 26 à p. 100bis está traduzida parte do volume de Franz Nikolaus Finck, Die Sprachstämme des Erdkreises (As famílias linguísticas do mundo), Teubner, Leipzig-Berlin 1923. (...) À p. 51 deste caderno aparecem ainda legíveis três linhas canceladas de uma tradução apenas começada (não se entende de que língua) do $O$ santo evangelho de João. Após o título, lê-se: 'Capítulo primeiro. No princípio era o verbo e o verbo era em (junto a) Deus, e o verbo era Deus. 2)Em princípio ele estava com Deus'. (Gerratana, in Quaderni, 1975, p. 2438)

Ultimamente, os cadernos de tradução, identificados pela edição crítica de Valentino Gerratana com A, B, C, D, suscitam bastante curiosidade junto aos comentaristas. Com razão. Um ditado da antiga filosofia escolástica diz: "in minimis videtur Deus" (tradução livre: nos detalhes se vê a deus). $O$ "detalhe" da citação confirma que a linguística era para Gramsci referência essencial.

\section{c) A questão do historicismo e da dialética.}

A suposição de uma leitura a-historicista dos textos gramscianos por parte dos educadores brasileiros ainda está sub judice. Talvez seja essa a questão mais importante e espinhosa. Minha compreensão sobre essa problemática ocorre progressivamente, aos poucos, por graus de profundidade teórica. No Ao Leitor (1르 edição), escrevi: "Como se ter dos escritos de Gramsci uma leitura historicista sem "ouvir" as acaloradas discussões que ocorriam nas praças, nas igrejas e nos partidos italianos sobre participação ou neutralidade na 1ํ Guerra Mundial?" (Nosella, 2010, p.23). 


\section{Trabalhonecessário}

Issn: 1808 - 799X

ano 13 , número $20-2015$

$\mathrm{Na}$ época (1992), visava apenas alertar para a necessidade de se contextualizar os textos estudados descrevendo fatos e dados relacionados ao momento em que os textos foram escritos, suas condições materiais, sociais e políticas. Com efeito, tudo isso é importante, mas insuficiente para uma leitura completamente historicista.

No epílogo da terceira edição (2004), reiterei minha crítica denominando-a "a linha de sombra do a-historicismo", sem negar, obviamente, as importantes contribuições teóricas e práticas da leitura desses textos para os educadores brasileiros.

Em vários debates, insisti nessa mesma crítica.

Saviani, na "Introdução sobre a recepção de Gramsci na educação brasileira" (Saviani, 2013, págs.13-19), desaprova as críticas de a-historicismo (e não somente as minhas ${ }^{5}$ ) dirigidas aos educadores brasileiros "mesmo com todas as limitações aí implicadas" (idem, ibidem, p.15). Conclui:

Enfim, penso que, além de atentar para o caráter historicista do pensamento de Gramsci e ao fazer sua leitura não perder de vista a necessidade de historicizá-lo, mais importante ainda é aprender com Gramsci o método da historicização, buscando aplicá-lo em todas as análises que fazemos teórica e praticamente no campo da educação.

Minha tendência pessoal, quase diria por temperamento, é a de considerar essas controvérsias estéreis e, mais do que isso, contraproducentes, paralisantes. Acredito, com Gramsci, que devemos sempre buscar a unidade de todos os que lutam pela transformação dessa sociedade, perseguindo constantemente o caráter unitário dessa luta. (Saviani, 2013, p. 18)

5 SOARES, R. D. Gramsci, o estado e a escola, ljuí: Editora Unijuí, 2000. VIEIRA, C. E. O conceito de formação humana no pensamento de Antonio Gramsci. Educação em Revista. Belo Horizonte, n. 37, jul. 2003.

. Cultura e formação humana no pensamento de Antonio Gramsci. Educação e Pesquisa: Revista da Faculdade de Educação da USP, São Paulo, v. 25, n. 1, 1999.

O historicismo gramsciano e a pesquisa em educação. 1994. Dissertação (Mestrado em História e Filosofia da Educação) na Pontifícia Universidade Católica de São Paulo, 1994. 


\section{Trabalhonecessário}

Issn: 1808 - 799X

ano 13 , número $20-2015$

Ou seja, o autor demonstra alguma irritação com as críticas de ahistoricismo feitas aos educadores brasileiros na leitura dos textos gramscianos.

Hoje, vinte e dois anos depois, lendo tais considerações de Saviani, sem entrar na consideração do caráter contraproducente ou não de eventuais controvérsias, considero importante frisar a necessidade de continuarmos o aprofundamento e a discussão sobre o historicismo de Gramsci. Essa categoria, com efeito, se conecta intimamente à concepção da dialética, princípio regulador de opções e comportamentos. Frequentemente, levanta-se (sobretudo entre os educadores) o nome de Gramsci como bandeira de luta, mas age-se alicerçados na filosofia de extração althusseriana, ou seja, críticos nas análises e conciliadores nas proposições. A concepção de história de muitos educadores é fundamentalmente gênese, evolução, quase uma história romanceada: socialista num mítico início, dramática no seu percurso e necessariamente triunfal na conclusão. Em outras palavras, é uma história economicamente determinada, sendo o socialismo o fruto automático do esgotamento das forças produtivas materiais do capitalismo.

$\mathrm{Na}$ retro cena do movimento filosófico anti-historista da $1^{\text {a }}$ metade do século XX, o historicismo apresentava-se, e com razão, para muitos filósofos, como a fundamentação teórica de trágicas ditaduras (exemplo: nazismos, fascismos e comunismos). O "historicismo" era utilizado ad usum delphini como ideologia que vê o presente como herdeiro de um fantasioso e glorioso passado e construtor de um igualmente fantasioso destino futuro. Por isso, o neopositivismo, o existencialismo, o estruturalismo, a fenomenologia denunciavam a miséria desse historicismo. O estruturalismo de Althusser, entretanto, livrou Marx da "acusação" de historicista, ensaiando uma convincente leitura estruturalista de suas obras, sobretudo de $O$ Capital. Entretanto, se a história do marxismo demostra que é possível uma leitura polissêmica de Marx (estruturalista e/ou 


\section{Trabalhonecessário}

Issn: 1808 - 799X

ano 13 , número $20-2015$

historicista) $)^{6}$ é impossível fazer dos textos gramscianos outra leitura que não seja historicista, melhor, absolutamente historicista, considerando, inclusive, que ele mesmo assim se auto define.

Aprofundar essa temática não é erudição, é procurar entender o que Gramsci queria dizer em suas inúmeras anotações. Para ele, historicismo não é gênese, menos ainda evolução, é dialética entre "práxis" e "filosofia", entre o objeto real e o objeto do conhecimento, é ferrenha oposição "de irmãos, isto é, oposição/ligação visceral, orgânica, entre a lógica dialética e a lógica formal. A "filosofia" é parte da "práxis"; mas, a práxis, continuamente, a transcende a própria filosofia, frustrando, ora mais ora menos, sua tendência de capturá-la. Com efeito, a lógica mental tenciona para formular uma conceituação cabal, completa, exaustiva do objeto do real, sem todavia conseguir apreender plenamente a grande complexidade "da história real, do processo dialético que se fragmenta em inúmeros momentos parciais" (Gramsci, ibidem, p. 292). Metaforicamente, podemos imaginar um fotógrafo que pretende retratar integralmente o grupo em movimento no qual ele mesmo está inserido: necessita que o grupo pare para enquadrá-lo na sua lente. Isso, obviamente, é impossível. Assim, retrata, na verdade, alguma parte, fragmentos. Só o filósofo moderno é consciente disso. Por isso, Gramsci, superando a dicotomia cartesiana, conceitua as categorias de "infra" e " superestrutura" em contínua e complexa inter-relação, representando simultaneamente a força econômica e cultural, a força emocional e fortuita, a necessidade e a liberdade, sem, todavia, cair no irracionalismo uma vez que admite ser a história do passado e a do presente objeto de análise; até mesmo do futuro, imprevisível, é possível elaborar categorias racionais para orientar a estratégia da luta política.

Os debates e as divergências teóricas entre educadores não prejudicam a unitariedade da luta, desde que sejam debates respeitosos e leais, visando ao 


\section{Trabalhonecessário}

Issn: 1808 - 799X

ano 13 , número $20-2015$

esclarecimento, como o próprio Gramsci fez, por exemplo, no Caderno 11, ao analisar o "Tratado de Materialismo Histórico" de Nikolai Bukharin (1980):

É preciso dizer que ao autor (Bukharin) foge o próprio conceito de metafísica, porque não compreende os conceitos de movimento histórico, de devir, e, logo, da própria dialética. (...) Conceber a filosofia como historicidade é operação mental um tanto árdua e difícil. (...) Ele não consegue elaborar o conceito de filosofia da práxis como 'metodologia histórica' e esta como 'filosofia', como a única filosofia concreta; não consegue se colocar e resolver do ponto de vista da dialética real o problema que Croce se pôs e procurou resolver do ponto de vista especulativo. (Gramsci, 1975, p. 1402)

Aprofundar o debate teórico sobre historicismo e dialética em Gramsci nos coloca ao nível do mais elevado debate teórico, fortalecendo lutas políticas contrahegemônicas:

É preciso - escreve em maio de 1932 - refazer, com referência à concepção filosófica de Croce, a mesma redução que os primeiros teóricos da filosofia da práxis fizeram com a filosofia hegeliana. È este o único modo historicamente fecundo para determinar uma recuperação adequada da filosofia da práxis - que, por necessidade de vida prática imediata, foi "vulgarizada"- para elevá-la à altura que deve alcançar para resolver os problemas mais complexos que o desenvolvimento atual da luta propõe, isto é, a criação de uma nova cultura integral, [...] É preciso que a herança da filosofia clássica seja não somente inventariada, mas também se torne vida operante, e para fazer isso, é preciso ter em conta a filosofia de Croce, isto é, para nós italianos sermos herdeiros da filosofia clássica alemã significa sermos herdeiros da filosofia de Croce que representa o momento mundial atual da filosofia clássica alemã. (Gramsci, 1975, p. 1233-34)

Croce e Gramsci, assim como ocorreu com Hegel e Marx, utilizam linguagens traduzíveis, invertendo suas assertivas. Descrevem, quase com os mesmos termos, o descompasso entre a operação da lógica formal, que visa à definição completa de um fenômeno, e o historicismo como sendo a logicidade, conscientemente complexa e dialética, do movimento histórico. Assim Croce: 


\section{Trabalhonecessário}

Issn: 1808 - 799X

ano 13 , número $20-2015$

O próprio surgimento da indagação sobre uma forma perfeita e definida de historicismo trai um modo de pensar anti-histórico. $\mathrm{O}$ historicismo é um princípio lógico; trata-se, de fato, da própria categoria da lógica; trata-se da logicidade em sua plena aceitação, a logicidade do universal concreto e, portanto, como já observamos, viva e sempre, mais ou menos, em atuação no espírito humano. Estava notavelmente viva e em atuação na época do historicismo. Mas, assim como nunca está ausente por completo em nenhum homem ou em nenhuma época, assim também em nenhum intelecto, por mais atuante e profundo, consegue assumir uma forma última e definida. (Croce, 2006, pp. 109-110)

Gramsci ecoa: "A dialética, isto é, a forma do pensamento historicamente concreto, ainda não tem uma versão de manual” (Gramsci, 2005, vol. 1, p.330). Comum aos dois pensadores é também a afirmação de que a lógica historicista é operação mental universal, atuante em todos os homens, pois todos pensam o real. Por isso, todos são intelectuais, embora nem todos tenham plena consciência disso, ou seja, todos somos historicistas ou dialéticos, de uma forma ou de outra, mas em graus e formas diferenciados.

De outro lado, as discordâncias teóricas e políticas entre Gramsci e Croce são conhecidas. Podem ser comprovadas por inúmeros exemplos: o universal concreto de Croce passa a ser a práxis em Gramsci; a dialética dos distintos de Croce passa a ser a dialética dos opostos em Gramsci; o individualismo e elitismo de Croce são substituídos pela histórica e revolucionária irrupção das massas no espaço da cultura e da política. Em suma: enquanto o historicismo de Croce considera o Estado Liberal como síntese histórica política imutável, para o historicismo de Gramsci, por isso qualificado de "absoluto", não existe a priori nenhuma síntese política enquanto forma definitiva de governo, nem o Estado Liberal, nem mesmo o Estado Socialista. O historicismo absoluto não prevê nada além da luta firme, obstinada e persistente entre os interesses do reino da necessidade (mercado) e os do reino da liberdade:

$\mathrm{Na}$ realidade, é possível prever 'cientificamente' apenas a luta, mas não os momentos concretos dela, que não podem deixar de 


\section{Trabalhonecessário}

Issn: 1808 - 799X

ano 13 , número $20-2015$

ser resultado de forças contrastantes em contínuo movimento, sempre irredutíveis a quantidades fixas, já que nelas a quantidade transforma-se continuamente em qualidade (Gramsci, 2004, p.121)

Ora, é justamente essa postura dialética a motivação fundamental para Gramsci defender uma posição política jacobina, não no sentido caricatural que a história atribuiu a esse termo, mas no seu sentido original. Para o jacobinismo, uma nova concepção de mundo tornou-se hegemônica com base na vontade nacional popular que, na Revolução Francesa, não só superou a velha estrutura social aristocrática, mas também não admitiu na nova estrutura democrática cidadãos de primeiro, segundo ou terceiro escalão. Em outras palavras, se a dialética é a luta profunda e radical entre tese e antítese, sem a previsibilidade de alguma forma conciliatória de síntese, ao militante cabe tão somente contrapor integralmente sua antítese:

$\mathrm{Na}$ luta, 'os golpes não são dados de comum acordo', e toda antítese deve necessariamente colocar-se como antagonista radical da tese, tendo mesmo o objetivo de destruí-la completamente. Conceber o desenvolvimento histórico como um jogo esportivo, com seu árbitro e suas normas preestabelecidas a serem lealmente respeitadas, é uma forma de história com uma meta predeterminada, na qual a ideologia não se funda sobre 0 'conteúdo' político, mas sobre a forma e o método da luta. Ė uma ideologia que tende a enfraquecer a antítese, a fragmentá-la numa longa série de momentos, isto é, a reduzir a dialética a um processo de evolução reformista 'revolução-restauração', na qual apenas o segundo termo é válido já que se trata de consertar continuamente (de fora) um organismo que não possui internamente os motivos próprios de saúde. (Gramsci, 1999, vol. 1. p. 396)

A concepção dialética como um jogo predeterminado, uma sequência ou evolução de fases ou tendências teóricas que se superam em perspectiva teleológica, cuja meta final é prevista como desfecho 'natural' do processo das crises do capital, faz parte da vulgata marxista que chegou, no ultra bolchevismo, a conceber a dialética sem a liberdade (Ponty, 2006). 


\section{Trabalhonecessário}

Issn: 1808 - 799X

ano 13 , número $20-2015$

Obviamente, vinte e dois anos depois, considero A escola de Gramsci fiel ao seu pensamento que politizava a economia por meio da unitariedade ou organicidade histórica entre liberdade e necessidade, rejeitando a justaposição entre essas dimensões. Todavia, há também nesse livro uma página que hoje gostaria de modificar, porque reflete posições teóricas deterministas, certamente opostas à concepção dialética de Gramsci. Ao comentar a proposta da escola unitária, afirmo ser o Caderno 12 "proposta educacional do Partido Comunista para a sociedade italiana caso os comunistas conquistassem o Estado." (Nosella, 2010, p. 161). Os termos são ambíguos. A proposta da Escola Unitária é a coerente e radical antítese política educacional contra a tese liberal que defendia (e defende) multiformes sistemas de ensino básico: um sistema de escolas humanistas, de elevada qualidade, com latim e grego, para os futuros dirigentes (poucos) e outro sistema subalterno, profissionalizante, nos diferentes ramos produtivos e de serviços, para a massa trabalhadora.

Mas, de um livro não se cancelam páginas ou afirmações que refletem momentos e posições do passado. Esclarecem-se equívocos redigindo novas páginas.

\section{d) A questão da escola unitária do trabalho}

Recentemente, o arquivo russo da família da esposa de Gramsci, Giulia Schucht, foi aberto para o público. Assim, dispomos de uma fonte importante para o estudo. De onde Gramsci emprestou a nomenclatura (e a ideia) de "escola unitária do trabalho"? Para responder a essa pergunta, por exemplo, é importante conhecer melhor Eugênia, irmã mais velha de Giulia, e suas relações com Gramsci. No livro I miei nonni nella rivoluzione - gli Schucht e Gramsci (Os meus avós na revolução - os Chucht e Gramsci), de autoria do neto Antonio Gramsci Junior, no capítulo onde retrata Eugênia, tia avó, que, já em 1916, era professora primária em Moscou, se lê: 


\title{
Trabalhonecessário
}

Issn: 1808 - 799X

ano 13 , número $20-2015$

\begin{abstract}
Eugênia começou a desenvolver um enorme trabalho bolchevique, em Moscou, em 1917. Durante a sabotagem dos professores primários, que abandonaram as escolas elementares da cidade, ela enfrentou e continuou a trabalhar com as crianças. Mais tarde [foi trabalhar] no Comitê Popular da Instrução Pública (Narkompros), onde foi membro do Collegio [Colegiado] da Escola única do trabalho e colaborou na fundação do novo Sindicato dos Trabalhadores da Instrução. (...) O ano mais feliz e proveitoso da vida de Eugênia foi talvez o de 1918, quando colaborou com a mulher de Lênin, Nadezda Krupskaja, no Comissariado do povo para a instrução. Lembra em sua autobiografia: '(...) precisava criar a nova escola soviética; formavam-se os novos quadros dos professores e a União que os reunia firmemente. Nessa direção eu trabalhava no Comissariado como membro do colégio da Escola unificada do trabalho, como vice chefe da seção da educação social e secretária do Comitê executivo do Sindicato dos Trabalhadores da Instrução que então estava se formando. (Gramsci Júnior, 2010, pp. 108-109. Negritos meus)
\end{abstract}

Eugênia era amiga de Kruskaja, esposa de Lênin. No ano de 1918, trabalhou no Comissariado do Povo para a Instrução. Ela escreve:

Naquele período faziam-se experimentações e inovações audaciosas no sistema escolar: todos os alunos deviam dedicar grande parte de seu tempo para o trabalho manual, muitos velhos livros escolares foram proibidos. Apesar disso, a Pública Instrução fez um grande passo a frente. (Gramsci Júnior, 2010, pp. 108-109)

É importante informar que Eugênia adoeceu no final do ano de 1919 e ficou internada por 4 anos (paralisia das pernas) no sanatório 'Serebrjanyj bor' (Floresta de prata), nos arredores de Moscou. Gramsci, em maio de 19 vinte e dois, a conheceu nesse sanatório e com ela manteve longas conversas. Em seguida, em agosto do mesmo ano, conheceu Giulia sua irmã. Eugênia nutria sentimentos de admiração e afeto para Gramsci, o qual, porém, se apaixonou por Giulia com quem se casou. Em que pesem os conflitos de caráter afetivos, manteve sempre profunda admiração por Eugênia. Ora, considerando que também Giulia era militante bolchevista, é fácil concluir que entre os três houve muitas conversas 


\section{Trabalhonecessário}

Issn: 1808 - 799X

ano 13 , número $20-2015$

sobre reforma escolar. Gramsci fazia visitas às fábricas, onde proferia palestras aos operários sobre cultura, educação e movimento comunista italiano e internacional. Giulia era guia, tradutora e até tocava no seu violino belas músicas populares russas e de Beethoven (Gramsci Junior, 2010).

Por essas informações, é fácil responder à pergunta: "De onde Gramsci emprestou a nomenclatura e o conceito de Escola Única do Trabalho?". Da mesma forma, porém, que questiona a tese de Lênin sobre as três fontes e partes integrantes do marxismo, questiona o sentido dessa escola. Duas palavras fortes: "única" e "trabalho". No caderno 11, § 62, relembrando o programa educacional de abril de 1917, especificamente "no parágrafo dedicado à escola unitária" (Documento para a Revisão do Programa de Partido), faz questão de destacar que "unitário" para Lênin "tinha significação demonstrativo-teórica de um princípio político." (Gramsci, 1999, vol. 1, p. 206). Ou seja, a escola única, mais do que uma questão didática, era para Lênin uma demonstração da política. Assim, a "Escola do Trabalho", amputada do termo "único" (ou unitário), perderia todo sentido gramsciano. Da mesma forma, o termo "trabalho" é por Gramsci dilatado no sentido de que "estudar" também é trabalho muscular nervoso. Enfim, a experiência educativa do bolchevismo de 1917, mais do que um modelo a ser imitado, é uma inovação a ser aprofundada e um movimento a ser levado adiante, pois "é necessário definir exatamente o conceito de escola unitária, na qual o trabalho e a teoria estão estritamente ligados: a aproximação mecânica de trabalho e teoria pode ser um esnobismo." (Gramsci, 1999, vol. 2, p. 175).

Em suma, Gramsci contrapõe-se tanto à proposta liberal de uma escola humanista para poucos, defendida por Gentile, quanto à proposta positivista defendida, na sua essência, também pelos socialistas reformistas, que propunham a ampliação do sistema educacional profissional e técnico para as massas, criticando a escola secundária clássica considerada elitista:

Gramsci rejeitava a ideia do desenvolvimento histórico defendido pelos socialistas para os quais o proletariado deveria se aliar com a parte mais avançada da burguesia que assim estaria colocando 


\section{Trabalhonecessário}

Issn: 1808 - 799X

ano 13, número $20-2015$

lealmente [sic!] seus conhecimentos técnicos a serviço do socialismo. Ao contrário, defendia a criação de um movimento de massa realmente jacobino, capaz de levar o proletariado à conquista da 'hegemonia' não somente econômica, social e politicamente, mas também culturalmente. Foi com essa bandeira que estava entre os fundadores do Partido Comunista Italiano em 1921. (Geimonat e Tisato, 1973, p. 526)

Com inegável satisfação, vinte e dois anos depois, reafirmo o que escrevi então: que a escola de Gramsci é de natureza 'desinteressada', isto é, de formação humanista, não utilitária; que seu princípio educativo fundamental é o trabalho industrial moderno enquanto busca da liberdade de todos os homens. Hoje, não poderia esquecer o atual debate sobre Ensino Médio que, se não é propriamente um novo debate, ganhou novo impulso. O Ensino Médio no Brasil é o punctum dolens do sistema escolar, por apresentar estatisticamente um quadro muito frustrante. Neste debate, a proposta curricular tida "teoricamente" a mais avançada é a do Ensino Médio Integrado à Educação Profissional, como Travessia para a Educação Politécnica ou unitária. Uma vez que, para a fundamentação desta proposta, recorre-se também (ou sobretudo) a Gramsci, caberia acrescentar algumas explicações.

Do ponto de vista linguístico-conceitual, joga-se com ambiguidade. "Integrado" é um conceito ao qual se recorre em quase todos os momentos e reformas escolares, com variadíssimos objetivos políticos. Aliás, as mais rebuscadas definições de "integração" entre cultura geral e formação profissional encontram-se nos pareceres do Grupo de Trabalho criado pelo Decreto n. 66.600 de 20 de maio de $1970^{7}$ que fundamentou a elaboração da Lei 5692/71. Como exemplo, citemos trecho do seu Relatório: "A estrutura que preconizamos fundase na ideia de integração: integração vertical dos graus escolares, integração horizontal da modalidade de habilitação em que estes se diversificam" (Brasil, 1971, p. 132. In Sabbi, p. 117).

7 O Grupo de Trabalho era composto por nove membros: Pe. José de Vasconcello (Presidente), Valnir Chagas (Relator), Aderbal Jurema, Clélia de Freitas Capanema, Eurides Brito da Silva, Gildásio Amado, Magda Soares Guimarães e Nilse Pires (Brasil, 1971, p. 130). 


\section{Trabalhonecessário}

Issn: 1808 - 799X

ano 13 , número $20-2015$

O ministro Jarbas Passarinho, ao submeter esse Relatório ao Conselho Federal de Educação, acrescentava:

Não há mais lugar, no Brasil de hoje, para o dualismo de uma escola média que leva à universidade e outra que prepara para a vida. A escola é uma só e deve sempre cumprir essas duas funções, indispensáveis a uma educação verdadeiramente integral. (Brasil, Passarinho, 1971 a , in Sabbi, p. 119)

Preliminarmente, sabemos que não existe, na concretude, nem o puramente teórico, nem o puramente prático; assim como não existem percursos formativos exclusivamente desinteressados, humanistas, e outros exclusivamente utilitários, profissionalizantes. Há percursos formativos que priorizam a racionalidade prático-utilitária à cultura especulativa, e outros, o contrário. Ou seja, a proposta do "Ensino Médio Integrado à Formação Profissional Técnica", à revelia de seus idealizadores, é um cavalo de Troia com um preciso intuito político: introduzir a profissionalização no Ensino Médio Regular.

Não existe complementaridade curricular entre o ensino médio de elevada qualidade e ensino profissionalizante popular mas oposição: um currículo para dirigentes e outro para dirigidos. A dualidade educacional se articula em variadas formas, similares ao sistema militar onde um soldado pode tornar-se suboficial desde que preserve a lógica da subalternidade. A lógica hierárquica do sistema escolar médio, grosso modo, pode ser sintetizado em três tipos de escola: "Profissional, Média Técnica, Clássica. A primeira para os operários e camponeses, a segunda para os pequenos burgueses, a terceira para a classe dirigente." (Gramsci, 1975, p. 825).

A citação se refere ao debate que se desenvolvia, em novembro de 1931, na Câmara dos Deputados, onde se discutia se as escolas profissionais deviam ser estritamente práticas e terminais, não permitindo transitar nem para a escola clássica, nem para a técnica. O avanço teórico político ( $\mathrm{sic}$ ) consistiu - comenta Gramsci - na afirmação de que se devia dar a possibilidade aos alunos das escolas profissionais de transitar para as escolas técnicas, uma vez que a 


\section{Trabalhonecessário}

Issn: 1808 - 799X

ano 13 , número $20-2015$

passagem para a escola clássica fora, unanimemente, excluída a priori. (Gramsci, idem, ibidem). Um ano mais tarde, sobre o mesmo argumento, volta a escrever:

È preciso lembrar a afirmação do Prof. G. Peano, para o qual, mesmo no Politécnico e nas matemáticas superiores são melhor preparados os alunos que cursaram o ginásio-liceu em comparação aos que cursaram os institutos técnicos. Essa melhor preparação é fruto do complexo ensino 'humanístico' (história, literatura, filosofia) conforme demonstrei mais amplamente em outras notas (sobre os 'intelectuais' e o problema escolar). (Gramsci, 1975, págs. 1892-1893)

Independente do fato de concordarmos ipsis litteris com as afirmações de Prof. Peano, a citação de Gramsci, que obviamente concorda com ele, referencia a direção de seu pensamento.

\section{Conclusão}

Ao reapresentar, vinte e dois anos depois, a obra $A$ escola de Gramsci, no momento em que entre nós ferve o debate sobre a reforma do Ensino Médio, identifico três grandes tendências teóricas:

\section{1a A mercadológica: escola técnica e profissionalizante}

Para os defensores desta tendência,

é inútil dar aos adolescentes uma preparação excessivamente literária se os problemas que vão encontrar são principalmente de natureza técnica. O essencial é ajustar os alunos, dependendo de sua classe econômica, ao mercado de trabalho (...). O objetivo de uma educação democrática deve ser o da formação individual, valorizando a criatividade pessoal, em termos de liberdade, seja quanto aos laços de objetivos políticos, de cultura ou de classe. (Silva, 1969, in Sabbi, 2014, p. 100) 


\section{Trabalhonecessário}

Issn: 1808 - 799X

ano 13 , número $20-2015$

É a tendência dominante. Prova disso é a aprovação, no Senado, da Rede Federal de Educação Profissional, Científica e Tecnológica aplaudida pela mídia como sendo:

um passo pequeno, ainda que na direção correta, para preencher uma das grandes lacunas na formação dos brasileiros: o ensino profissional. Para ser bem sucedida, é importante que essa aprovação contemple principalmente os alunos do ensino médio. (Folha de S. Paulo, Editorial, 28 de dez. de 2008)

\section{2a A reformista: Ensino Médio Integrado à Educação Profissional}

Essa tendência pretende, no currículo do Ensino Médio, "integrar" a cultura geral à formação profissional (E.M.I.), com base no argumento de que "o trabalho não intelectual" é elemento importante para um elevado percurso formativo. É uma proposta que parte de um lugar bem preciso do campo da política educacional, isto é, da atual proposta governamental, sobretudo, referente aos Institutos Técnicos. Fundamenta-se, como vimos, no conceito abstrato e ambíguo de "integração", utilizado por diferentes forças políticas em vários momentos da nossa história. Os defensores desta proposta afirmam ser oportuno, no atual estagio de desenvolvimento do Brasil, um sistema de Ensino Médio multiforme, isto é, ainda não unitário, respaldados na ideia de que não faz sentido ministrar um currículo altamente abstrato e humanista para os adolescentes mais pobres que precisam, em curtíssimo prazo, de uma profissão e de um salário.

\section{A revolucionária: a escola unitária do trabalho}

A tendência revolucionária fundamenta-se, de um lado, na concepção de que a unitariedade do Ensino Básico (infantil, fundamental e médio) é, antes de tudo, a demonstração de um princípio de política nacional igualitária; de outro lado, na concepção da dialética histórica contrária à política conciliatória dos "pequenos passos". Com efeito, uma vez que a síntese é sempre imprevisível e a tese (a proposta escolar neoliberal) luta ferrenhamente para conseguir integralmente a vitória, cabe ao militante apresentar sua antítese (escola unitária) 


\section{Trabalhonecessário}

Issn: 1808 - 799X

ano 13 , número $20-2015$

na forma plena e integral, defendendo a necessidade de massificar o objetivo do ensino secundário humanista que visa a formar dirigentes da sociedade.

Histórica e hermeneuticamente, pode-se qualificar essa tendência de "jacobina". O termo "jacobino" assusta. A ideologia e a literatura dominantes atribuíram a esse termo o sentido folclórico e caricato de "republicano ardente e intransigente". (Bobbio, 1990, p.438). Entretanto, "Jacobinismo é uma categoria histórico-interpretativa de primeira ordem para o Gramsci dos Cadernos do Cárcere" (Bongiovanni, 1990, p. 351).

Nos anos de Ordine nuovo 1919-1920, Gramsci se reconciliou com esse termo e o respectivo conceito que anteriormente havia rejeitado (Gramsci, v.1, 2004, p. 105). Por que mudou de ideia? Porque compreendeu o "sentido integral que a noção [jacobinismo] teve historicamente e deve ter conceitualmente", escreverá em 1932/34, no Caderno 13 (Gerratana, 1974, p. 1559). Portanto, resgatou o sentido de uma posição política ardente e intransigente referente à função das massas populares no processo histórico, focado na questão da relação hegemônica entre trabalhadores urbanos e do campo: "Os jacobinos lutaram denodadamente para garantir uma ligação entre campo e cidade e conseguiram vitoriosamente" (Bongiovanni, 1990, p.352). Jacobinismo, portanto, transmite o sentido de uma vontade política fortemente decidida a criar uma unitária vontade das massas do campo e da cidade em torno dos ideais de justiça, fraternidade e igualdade, rejeitando a ideologia dos "pequenos passos" (Galastri, 2013, págs. 89-112).

Para a concepção revolucionária, o ponto para alavancar a unificação política das massas não é a luta por uma escolarização básica pautada em objetivos utilitários, individuais e superficiais, mas por uma escola básica popular com a mesma qualidade das excelentes escolas existentes, conforme se vislumbra no nível mais profundo da consciência e vontade da massa: 


\section{Trabalhonecessário}

Issn: 1808 - 799X

ano 13 , número $20-2015$

exigência ideal. Com efeito, não existem, já agora, operários, aos quais a luta de classe deu um novo senso de dignidade e de liberdade, que quando leem os cantos dos poetas ou ouvem os nomes dos artistas e dos pensadores, se perguntam com tristeza: "por que a escola não ensinou essas coisas também a nós?". (Gramsci, 1975a , p. 174)

A citação foi extraída de um texto publicado no mês de agosto de 1919. Em dezembro do mesmo ano, num outro artigo "Studi difficili", motivado por um comentário de L'Humanité, órgão oficial do partido socialista francês, que elogiava a revista dirigida por Gramsci Ordine Nuovo "pelo elevado grau de desenvolvimento intelectual até o ponto de exigir do leitor um grande e prolongado esforço de atenção"(Gramsci, idem, ibidem), se lê:

Sim, é verdade, publicamos artigos "longos" e estudos "difíceis" e continuaremos a publicá-los, sempre que necessário, dada a importância e a seriedade dos temas; esta é a linha do nosso programa: (...) No campo da cultura, então, os trabalhadores e os camponeses foram e ainda são considerados pela maioria como uma massa de negros que se podem facilmente contentar com pouco, com as falsas pérolas e com os fundos de vidro, reservando aos eleitos os diamantes e outros bens de valor. Não há nada mais desumano e antissocialista que essa concepção. Se há algo no mundo que tem um valor em si mesmo, todos são dignos e capazes de apreciá-lo. Não existem duas verdades, nem duas maneiras diferentes de discutir. Não há nenhum motivo para que um trabalhador deva ser incapaz de alcançar o desfrute do canto de Leopardi mais do que uma guitarra, digamos, de Felice Cavallotti ou de outro poeta "popular"; uma sinfonia de Beethoven mais do que uma canção de Piedigrotta. (Gramsci, 1975르, p.469$470)^{8}$

Os Escritos Políticos (1911 e 1926) são a chave explicativa do código carcerário (1926-1937). Há um nexo profundo de coerência entre si, mesmo

8 Às vezes utilizamos textos de um autor "pescando" citações como bengalas de apoio à nossa tese. Isso não é correto. A boa hermenêutica, protegendo-nos desse erro, diz que devemos identificar a tese do autor no conjunto dos seus textos. Apliquemos essa hermenêutica no caso de Gramsci: todos seus textos (exemplos: Socialismo e cultura, A escola do trabalho, A escola vai à fábrica, Universidade popular, Homens ou máquinas?, A escola de cultura, Uma associação de cultura etc.) propõem uma escola secundária de elevada cultura humanista também para as massas de trabalhadores. 


\section{Trabalhonecessário}

Issn: 1808 - 799X

ano 13 , número $20-2015$

quando se expressam em formas diferentes. Assim, enquanto nos primeiros a verve jacobina transparecia de forma franca e aberta, nos cadernos e nas cartas do cárcere o jacobinismo era defendido de forma mais teórica e reflexiva, ao alertar, por exemplo, para a necessidade de tomar o jacobinismo "no sentido integral que essa noção teve historicamente e deve ter conceitualmente" (Gramsci, 1975, p. 1559).

Houve jacobinismo no movimento político italiano do Risorgimento? (Gramsci se faz essa pergunta e sua resposta é negativa). Na história do Brasil, houve algum movimento político social jacobino? Em geral, na leitura dos textos de Gramsci foi subestimada a dimensão jacobina? São perguntas para novas pesquisas.

\section{Referências Bibliográficas}

BOBBIO, Norberto; MATTEUCCI, Nicola; PASQUINO, Gianfranco. Dizionario di política. Verbete: Giacobinismo. Ed. UTET, Torino, 1990.

BONGIOVANNI, Bruno. Verbete, Giacobinismo. In: LIGUORI, Guido e VOZA, Pasquale. Dizionario gramsciano 1926-1937. Ed. Carocci, Roma, 2009.

BRASIL. Relatório do Grupo de Trabalho para a Reforma do Ensino de $1^{\circ}$ e $2^{\circ}$ Graus. In: Revista Brasileira de Estudos Pedagógicos, v. 56, n. 123, Rio de Janeiro: MEC/INEP, jul.- set., p. 130-168, 1971.

BUKHARIN, N. Tratado de materialismo histórico. Lisboa. Editora Peres, 1980. 382p.

CROCE, Benedetto. História como história da liberdade. Tradução Julio Castañon Guimarães. Rio de Janeiro: Editora Topbooks. 2006.

FOLHA DE S. PAULO (Jornal). Editorial, 28 de dez. de 2008.

GALASTRI, Leonardo de Oliveira. A construção do bloco histórico: via jacobina e o "debate" com Georges Sorel nos cadernos do cárcere. In: Gramsci no limiar do século XXI, Librum Editora. Campinas, SP, 2013.

GERRATANA, Valentino, Introduzione. In LABRIOLA. Antonio, Del materialismo storico. Editori Riuniti. Roma, 1974.

GIASI, Francesco (org.). Gramsci nel suo tempo. Prefácio Giuseppe Vacca. Roma. Editora Carocci. 2008.

GRAMSCI, Antonio. Quaderni del carcere. (4 vols.) Edição de Valentino Gerratana. Torino. Editora Einaudi, 1975. L'Ordine Nuovo (1919-1920. Torino: Giulio Einaudi Editore.1975a․ 


\section{Trabalhonecessário}

Issn: 1808 - 799X

ano 13 , número $20-2015$

Cadernos do cárcere, (6 vols.). Edição e tradução, Carlos Nelson Coutinho; co-edição, Luiz Sérgio Henriques e Marco Aurélio Nogueira. Rio de Janeiro; Civilização brasileira, 1999.

Cartas do cárcere. (2 vols.). Edição Carlos Nelson Coutinho e Luiz Sérgio Henriques. Civilização Brasileira. Rio de Janeiro 2005.

Escritos Políticos. (2 vols.). Organização e tradução Carlos Nelson Coutinho. Rio de Janeiro. Editora Civilização Brasileira. 2004.

GRAMSCI JÚNIOR, Antonio. I miei nonni nella rivoluzione: gli Schucht e Gramsci. Ed. II Riformista. Roma, 2010.

LABRIOLA, Antonio. Del materialismo storico. Curado por Valentino Gerratana. Roma: Editori Riuniti. 1974.

LIGUORI, Guido; VOZA, Pasquale (org.) Dizionario Gramsciano (1926-1937). Roma. Editora Carocci. 2009.

LOMBARDI, Claudinei José; MAGALHÃES, Livia Diana Rocha; SANTOS, Wilson da Silva (org.) Gramsci no limiar do século XXI. Campinas, Librum Editora, 2013.

MANACORDA, Mario Alighiero, Marx e a pedagogia moderna. Tradução de Newton Ramos de Oliveira. Campinas-SP: Editora Alínea, 2007.

MARTINS, Maurício Vieira. "O marxismo não é um historicismo": acertos e limites de uma tese althusseriana. In: Crítica marxista, n. 34, p. 67-85, 2012.

NATOLI, Aldo. Antigone e il prigioniero. Editori Riuniti, Roma, 1990.

NOSELLA, Paolo. A escola de Gramsci. 4 ed. São Paulo-SP: Cortez editora. 2010.

PONTY, Maurice Merleau. As aventuras da dialética. Tradução Claudia Berliner; revisão técnica e da tradução Márcia Valéria Martinez de Aguiar. São Paulo. Editora Martins Fontes, 2006.

SABBI, Volmir. Políticas educacionais no Brasil: a dualidade educacional nas trajetórias de escolarização e profissionalização. Tese de doutorado, PPGE-UEM. Maringá, 2014.

SAVIANI, Dermeval, Apresentação à $3^{\underline{a}}$ edição in A escola de Gramsci. São Paulo. Editora Cortez. 2004. págs. 11-20.

Introdução: sobre a recepção de Gramsci na educação Brasileira. In: LOMBARDI, Claudinei José; MAGALHÃES, Livia Diana Rocha; SANTOS, Wilson da Silva (org.) Gramsci no limiar do século XXI. Campinas, Librum Editora, 2013. Págs. 13-19.

SCHIRRU, Giancarlo. La categoria di hegemonia e il pensiero linguístico di Antonio Gramsci. In: Egemonie, coordenador Angelo d'Orsi com a colaboração de Francesca Chiarotto. Ed. Libreria Dante \& Descartes. Napoli. 2008. Pp. 397-444.

Antonio Gramsci studente di linguística. Studi storici. Rivista trimestrale dell'Istituto Gramsci, LII , Roma, 2011, pp. 925-73.

SILVA, Monica Ribeiro da (org.). Ensino médio integrado: travessias. CampinasSP: Mercado das Letras, 2013.

VACCA, Giuseppe. Antonio Gramsci 1926-1937: la linea d'ombra dei rapporti con il Comintern e il partito. Roma, Instituto Gramsci, julho 1992.

Vita e pensieri di Antonio Gramsci (1926-1937). Torino: Editora Einaudi, 2012. (em língua portuguesa: idem. Vida e pensamento de Antonio Gramsci 
Issn: 1808 - 799X

ano 13 , número $20-2015$

(1926-1937). Tradução de Luiz Sérgio Henriques. Brasília: Fundação Astrojildo Pereira: Rio de Janeiro: Contraponto, 2012.

VIEIRA, Carlos Eduardo. O historicismo gramsciano e a pesquisa em educação. In: Perspectiva. Florianópolis, UFSC/CED, NUP, V. 11 n.20, 1993. p. 31-51.

Recebido em 15 de novembro de 2014 Aprovado em 20 de janeiro de 2015 